\title{
Prediction of Investment Alternatives with Artificial Neural Network
}

\author{
Ayşe YILDIZ iD a Doğan YILDIZ iD a \\ a Ankara Hacı Bayram Veli University, Faculty of Economics and Administrative Sciences, Ankara, Turkey. ay.yildiz@hbv.edu.tr \\ b Turkish Aerospace Industries, Inc. (TUSAS), Ankara, Turkey. dyildiz2000@gmail.com
}

\section{ARTICLE INFO \\ Keywords: \\ Artificial neural network Prediction \\ Investment alternatives}

Received 15 June 2021

Revised 5 October 2021

Accepted 20 October 2021

Article Classification:

Research Article

\section{ABSTRACT}

Purpose - Since investment decisions are made in an uncertain environment, it is vital to develop prediction models that enable investors to make the right decision on time. Artificial neural network (ANN) method is one of the most widely used for this purpose. Thus, in the study, USA dollar Exchange rate, BIST 100 index, gold price in ounce and TL deposit interest rate are determined as alternative investments and their future values are predicted by using ANN models. The lag values of each investment alternative with other investment alternative values are considered as influencing variables. Hence, it is aimed to develop multidimensional prediction models.

Design/methodology/approach - In the study, a multilayer artificial neural network model was used. As a data set obtained from the Central Bank database, 284 weekly data for the period of January 2015 and June 2020 were included in the analysis. Of this data set, 238 were used for training and 46 for testing. In the models, the lagged values of each variable and the influencing variables are included in the model as independent variables. Model trials were carried out over the hyperbolic tangent and logistic activation functions for each variable. As the error function, the sum of the squares of the error was chosen. The fast back propagation algorithm was used as the learning algorithm.

Findings - ANN models were built with the dataset and processed with algorithm specified in the method part. Prediction values for each investment alternative were obtained by choosing the model with the smallest mean squares error among constructed all the models. The fact that the chosen prediction model results in very low error rates reveals that the prediction performances of the models are quite well. In addition, obtaining over $93 \% \mathrm{R}^{2}$ values indicating the explanatory power of these models implies the validity of the them.

Discussion - Predicting the future value of alternative investments for investors minimizes the possible risks they may encounter. Developing models such as neural networks by identifying appropriate influencing variables provides investors to do this. This study developed multidimensional models by analyzing both the relationship between alternative investments and their own lagged values. As a result, the lagged values of investment alternatives were found to be effective. This result reflects the situation that supports the assumption that the structure shown in the past will continue in the future. In fact, this imply that the effects of causal variables have been already reflected in their past values. Hence, it can be stated that ANN models based on time series data might be more preferable than models using influencing data. However, in this case, the break points or periods specific to time series analysis should be taken into account and the autocorrelation problem should be considered. Thus, it will be ensured that the prediction performance of the models emerges with better results. In addition, the better prediction values can get in shorter time by generating models with optimal parameter values.

\section{INTRODUCTION}

Uncertainty is emerging more and more in human and business life day by day, and this leads to the necessity of making many decisions in an uncertain environment. Financial markets are also the environments where uncertainty is most observed, and that makes difficult for investors to make wise investment decisions. For this reason, it has been continuously made an effort to predict financial and economic variables in order to reduce uncertainty and to ensure making more effective decisions. In line with these efforts, various different methods have been developed both in literature and in practice. ANN is a leading method in the field of prediction as a method designed similar to thinking and decision-making process of human being. In some of these studies, ANN was used as a single method to predict financial and economic variables. Some studies have been carried out based on the comparison of the prediction performance of the ANN with other methods. 


\section{A. Y1ld1z - D. Yildiz 13/4 (2021) 3103-3118}

In some other studies, hybrid (mixed) models have been developed together with econometric methods. In all these studies, emphasis is placed on the methods and models created accordingly. In these studies, time series data taking into account the lag values of the variables or dataset containing other influencing factors have been used.

As far as the reviewed studies have been concerned, it has been found that the number of prediction models including more than one variable with both its own lag values and influencing variables is quite low. However, for a good prediction, it is very vital to use correct and appropriate decision variables which are inputs of the models as much as the model used and /or developed. It should be considered that all predictions are actually made for decision making which is a process that requires evaluation of alternative options together. Therefore, regarding investment decisions, inputs can be taken as USA dollar exchange rate, BIST 100 index, gold price in ounce and TL deposit interest rate. In this study, to determine prediction values of these investment alternatives, which can be considered as alternatives to each other, different ANN models were constructed by taking into account the lag values of each alternative and the values of other investment alternatives together. With these models, it is aimed to ensure that the dollar investor, who considers it as an investment tool rather than currency, the gold investor who seeks a safe haven, stock exchange market investor who loves risk and interest investor who averse the risk might be supported to make correct and effective decisions and finally make profits.

In this context, the study consists of four parts. In the following part, the studies regarding ANN method are reviewed. In the method part, basis of the theory with the process carried out in ANN is presented. In the analysis part, ANN models are constructed for prediction of USA dollar exchange rate, BIST 100 index, gold price in ounce and TL deposit interest rate, respectively. Based on the findings, interpretations are made to help investors in their decisions. In the conclusion and recommendation part, general evaluation of this study has been made and some suggestions are also offered.

With this study, ANN models were constructed in some way with multivariate way using more than one variable simultaneously. Thus, in this way evaluation of investment alternatives was ensured for different instruments depending on each other.

\section{LITERATURE REVIEW}

In the financial field, there has been many studies conducting ANN method in the prediction of financial variables that do not exhibit linear structure in the uncertain environment. As to application methods, some of these studies used only ANN as prediction method and some others constructed hybrid methods combining conventional methods such as ARIMA and neural networks. Regarding data in these studies, it can be observed that both time series data and causal dataset were included.

Yavuz et al. (2020) conducted study titled Bitcoin Price Prediction Based on Artificial Neural Networks and Blockchain Data. They got 99\% prediction success for bitcoin price in future. Şeker et al. (2004) predicted different exchange rates with ANN in their study called Applying ANN in Economic Forecasts. Özkan (2011) stated that the ANN prediction model created with lags of USA dollar and Euro values resulted in more successful prediction than with the purchasing power parity and variables of the monetary model. Çalışkan \& Deniz (2015) made daily predictions for the price of BIST 30 index using many financial and economic data by ANN and stated that they predicted it 58\% correctly. Kocatepe \& Oktay (2016), achieved approximately $75 \%$ percent prediction success in the direction of the change for gold price based on numerous economic factors. Yüksel \& Akkoç (2016) conducted an ANN model to predict gold price by using some affecting variables such as silver prices, Brent oil prices, Dow Jones index etc. and found ANN can be successfully applied to predict it. They also revealed that silver and oil prices were the major factors affecting the gold price. Persio \& Honchar (2016) made forecasts conducting various ANN models in their study called Artificial neural networks architectures for stock price prediction: comparisons and applications. Galeshchuk (2016) predicted three different exchange rates with ANN models and got very good results in short term forecasting. Yu \& Yan (2019) indicated that deep neural network can produce higher prediction accuracy because it is more useful for nonlinear problems like financial dataset and events than conventional machine learning algorithms. Conducting ANN algorithm for Indian stock market prediction, Selvamuthu et al. (2019) expressed that they obtained results with 99\% accuracy in their study. Nwokike et al. (2020) developed 17 different ANN models and they predicted a decline in gold prices by applying the best one ANN model 


\section{A. Yildız - D. Yıldiz 13/4 (2021) 3103-3118}

chosen. Çınaroğlu \& Avcı (2020) carried out many ANN models to predict the stock values of Turkish Airlines traded in BIST based on such inputs as BIST 100, BIST Transportation indexes, oil and dollar prices and got the results very close to the real values of the stock values. Barkhatov et al. (2020) declared that neural network models have great importance in processing big data and are good solution for a labor-intense process to forecast the stock market by running powerful softwares. Yildiz (2021) conducted the study regarding the prediction of consumption credit interest rate during Covid-19 pandemic period using ANN model.

In other studies, hybrid models have been implemented in order to combine the advantages of other methods with neural network method. One of these studies was carried out by Zhang (2003) to create the hybrid model by combining Autoregressive Integrated Moving Average (ARIMA) and neural network. The study revealed that the hybrid model can have more forecasting accuracy than each models alone. A similar analysis was conducted by Yildız \& Yıldız (2014) and obtained the similar result. İnce \& Çakır (2017) also found that the hybridizing models gave better estimation results than single models in estimating NASDAQ stock market index values.

It can be observed that in the literature the most common application of ANN models has been based on the comparison of performance of ANN models with other forecasting methods. Zhang et al. (1999) declared that ANN models were significantly better than in bankruptcy prediciton in terms of classification rate and sampling varition than logistic regression. Polat \& Temurlenk (2011) predicted the Manufacturing Industry Production Index with ANN method and compared with the Manufacturing Industry Education predictions, and as a result, they revelaed that the ANN model has better result. Aygören et al. (2012) developed traditional time series, numerical search and ANN models using five different variables for ISE 100 index prediction and then compared the results of these models. Model comparisons indicated that traditional time series and numerical search models had less performance than ANN models. Akel \& Karacameydan (2012) compared regression model with ANN model in their study and indicated that ANN models developed to predict the net asset values of mutual funds gave much better results than regression model. Benli \& Yildiz (2014) have used simple exponential smoothing and Holt's linear trend analysis with ARIMA and ANN methods to predict gold price and made comparisions among them. In contrary to many other studies, they found that ARIMA model produced much better prediction results. The other study made by Şahin (2018) displayed ANN model had much better performance than ARIMA model to predict bitcoin price. Hosaka (2018) brought about that ANN models achieved more success than other methods in his study called Bankruptcy Prediction Using Imaged Financial Ratios and Convolutional Neural Networks. In Kantar study (2019), the prediction of BIST 100 was made based on numerous economical and financial inputs applying ARMA and ANN models and found that prediction performance of ANN was better than ARMA model. All these results indicated because of the nonlinear pattern of financial data ANN models have much more prediction success and more appropriate to model for variables demonstrating wavy circulates.

There are many studies in which ANN method has been applied for prediction in different fields other than financial area. Regarding its use in the energy sector, Kaynar et al. (2011) predicted natural gas consumption employing both classical time series (ARIMA) and ANN and then compared the results. They expressed that ANN models performed better than ARIMA models. Ataseven (2013) worked on both ARIMA and ANN models for prediction of sales of one company and it was found that the results of ANN were more successful. Çuhadar (2013) tried to predict tourism demand with ANN methods in his study titled Modeling and Forecasting Inbound Tourism Demand to Turkey by MLP, RBF and TDNN Artificial Neural Networks: A Comparative Analysis. Es et al. (2014), in their study called Forecasting the Net Energy Demand of Turkey by Artificial Neural Networks, obtained the prediction performance of ANN model comparatively with the linear regression method and they expressed the superiority of ANN in their comparisons. In the study conducted by Akyurt (2015) ANN modelling employed for prediction of domestic automobile demand. Karahan (2015) used ANN modeling to predict monthly tourism demand.

All these various studies imply that ANN can be used as an effective method for prediction in many different areas. After reviewing literature regarding ANN method, it is time to provide the logic behind the process of the modeling. The next part is devoted to this theoretical knowledge. 


\section{METHOD}

The basic idea in prediction modelling is that future outcomes are based on the patterns of the past and this pattern will continue in the incoming periods. This modelling ensures that this pattern from the past is captured and adapted to the future and predicts the future in this direction. ANN is the most well-known method for prediction because it allows processing both linear and non-linear data and, unlike other conventional prediction methods, can be developed without any predefined function. Similar to human brain, ANN based on learning via computer programming by taking historical data as inputs and develop a prediction model and use this model to come with results for future by inserting new inputs (Y1ld1z, 2009). The following part presents components of this network.

\section{Neurons}

Neurons form the basis of the ANN model. Neuron consists of inputs, weights, summation function, activity function and outputs, as seen in Figure 1.

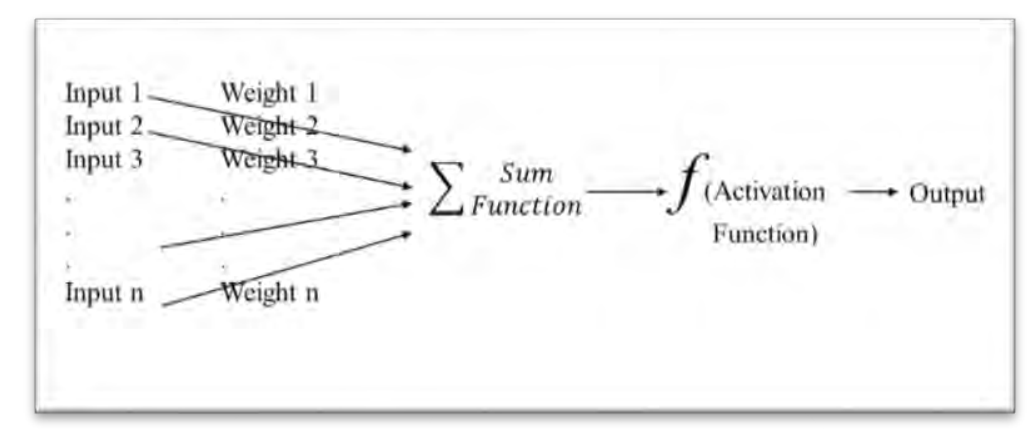

Figure 1. Neuron

Inputs: The values of inputs can be obtained either feature of a sample of external data or outputs of other neural neurons. If the input values are not the same scale, it may have needed to convert them as 0-1 range scale using normalization formula as illustrated in Equation 1.

$X_{1}=\frac{X-X_{\min }}{X_{\max }-X_{\min }}$

$\mathrm{X}_{1}$ : Converted new input value

$X$ min: The minimum value in the input set

$X \max$ : The maximum value in the input set

$X:$ Input values

Connections and Weights: Connections provide the output of one neuron as input to another neuron. Neuron may have multiple input and output connections. Weights are assigned to each connection to represent its relative importance. Weights can take negative, positive or zero value. Warner \& Mista (1996), in their study, found that the negative values of weights cause a decrease on the inputs whereas positive weight values have increasing effect on the inputs.

Weighted Sum Function: Although different functions are applied at this stage, the most one used is to find the weighted sum and it is calculated by Equation 2 .

$$
\mathrm{U}_{\mathrm{k}}=\sum_{i=1}^{n} w_{n} x_{n}
$$

Activation Function: The activation function processes the input to the neuron and determines the output as an outcome in response to this input. Sigmoid, hyperbolic tangent, threshold values are the most activation functions used. Equation 3 demonstrates the formulation of sigmoid and hyperbolic tangent functions, respectively. 
$f($ net $)=\frac{1}{1+e^{-n e t}}, \quad f($ net $)=\frac{\left(e^{n e t}+e^{-n e t}\right)}{\left(e^{n e t}-e^{-n e t}\right)}$

Outputs: The artificial neuron has multiple inputs and single output. This output can be used as an input for itself or other neurons or outcomes of the model.

\section{Learning Process}

The outstanding feature of ANN models distinguishing them from the others is that they have learning ability. This learning can be achieved by creating or updating links among neurons through weights. In the first stage, the weights are randomly assigned and start updating weights based on the connection or relationship between the inputs and outputs. Finally, if the network is able to generalize this relationship, ANN can gain the ability to learn.

This learning process is conducted by including the training dataset. Then, whether this training is successful or not can be controlled via testing dataset. The process mostly based on the called Hebb, Hopfield or Kohonen rule. According to this rule, the training of the network process continues by feeding it forward and backward until the minimum or least error is gained. As Haykin (1999) reported in his study, learning and memory are incomprehensibly linked and when something is learned, this is stored in the brain and recalled for use when needed. ANN learning process is based on this logic.

\section{Error Computations}

Computation of prediction error calculated by equation 4 .

$e_{t}=Y_{t}-\bar{Y}_{t}$

$e_{t}$ : Prediction error,

$Y_{t}$ : Real value,

$\bar{Y}_{t}:$ Prediction value

In this context, mean square error, mean absolute error, mean percentage error and finally the mean absolute percentage error can be used as an error calculation method.

\section{Network Architecture}

ANN architecture requires to determine the number of inputs, outputs, neurons and hidden layers. There are basically two architectures which are single layer and multilayer architectures. Single layer neural network is component of only one input and one output layer Since single-layer ANN cannot solve nonlinear problems, multilayer ANN architectures are developed by adding hidden layers to the single layer. Figure 2 illustrates the most widely used multilayer architecture.

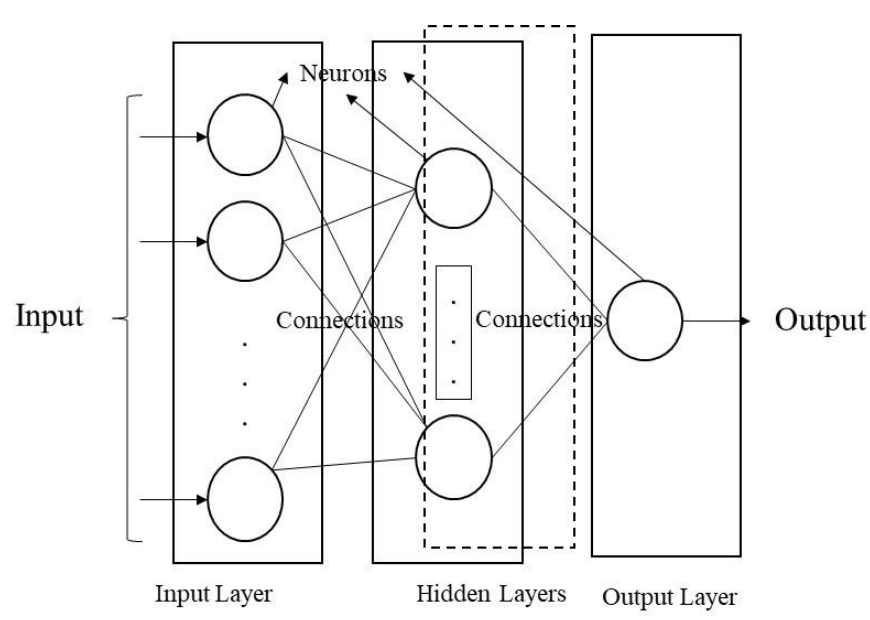

Figure 2. Multilayer ANN architecture 


$$
\text { A. Y1ld1z - D. Yıldiz 13/4 (2021) 3103-3118 }
$$

The neurons in the hidden layer process the input they receive from the input layer and transmit it to output layer or the next layer. Each neuron here is connected to all neurons in the output layer. In a multilayer ANN, there may be more than one hidden layer and more than one neuron in each hidden layer.

The neurons in this layer have processors providing non-linear properties to the network. Gradojevic \& Yang (2000) stated in their studies that the number of hidden layers is determined by the trade-off between the intuitive ability of the network and its efficiency. They also indicated that having too many hidden layers may cause some problems which lead to overtraining or overfitting of the network whereas having few hidden layers may cause not to reveal the structure pattern between the input and output. As a result, they reached the conclusion that the number of hidden layers and neurons must be determined by experiment because the optimum number of them is not clear.

\section{Network Model}

Each neuron in the output layer receives multiple inputs, processes them and then produces the outcomes.

Equation 5 illustrates the ANN model having one hidden layer.

$$
\begin{aligned}
y_{k}=f_{k}\left(\alpha_{k}+\sum_{j=k} w_{j} f_{j}\left(\alpha_{j}+\sum_{i=j} w_{i j} x_{j}\right)\right) \\
y_{k}: \text { Output value } \\
f_{k}: \text { Transfer function in output layer } \\
\alpha_{k}: \text { Deviation value of the output layer } \\
w_{j}: \text { Weights of the output layer } \\
f_{j}: \text { Transfer function of the hidden layer } \\
\alpha_{j}: \text { Deviation value of the hidden layer } \\
x_{j}: \text { Input values } \\
w_{i j}: \text { The weights between input layer and hidden layer }
\end{aligned}
$$

If the number of hidden layers increases, a new form of the equation can be obtained by adding each layer to the equation. Kaastra \& Boyd (1996) reported that ANNs are similar to linear and nonlinear least squared regression and are alternative statistical approach to solve least squared problems. In both ANN and regression methods, it is aimed to minimize error and the deviation in ANN is similar to intersection in regression. Inputs represent the independent variables and output represents the dependent variable in the regression. They also stated that linear regression models can be seen as ANN with no feed forward hidden layer, an output neuron and a linear transfer function. The neural network including hidden layer performs operations similar to regression model. The weights in the connections of the network can be considered as the curve parameters in the regression.

\section{Networking Development Process}

Networking development processes include the following stages:

1. Determine dataset: At this stage, the data to be used in the model are obtained. Then the data are divided into two groups as training and test sets. The test set can be chosen randomly from the whole dataset or obtained as series following the training set. If inputs have different scales, it may be necessary to use normalization formula to get normalized inputs.

2. Determine ANN architecture: This stage includes to determine the number of hidden layers with neuron numbers. The activation function also must be determined with these. This stage as an art of state requires taking into account different recommendations from practice and the expert having experience with the modelling. 


$$
\text { A. Yildiz - D. Yildiz 13/4 (2021) 3103-3118 }
$$

3. Train the Network: The network constructed based on the dataset obtained in the first stage and the architecture developed in the second stage is trained by updating weights. This process continues until prediction error drops a certain level. According to the results obtained, different architectures are examined and the learning process can be repeated by reconstructing the architecture.

4. Deployment model: The network whose training and testing steps are completed can be implemented if appropriate. At this stage, the reliability of outputs must also be evaluated in case of any problem encountering in practice.

\section{DATASET}

In the study, the ANN models are developed to predict USA dollar exchange rate, BIST 100 index, gold price in ounce and TL deposit interest rate as alternative investments. The influencing factors (model inputs) of each variable are determined as their lag values and other alternative values. The following functions demonstrate the inputs for predicted variables.

USA Dollar Exchange Rate $=\mathrm{f}$ (Lag values of USA dollar exchange rate, BIST 100 index, Gold price in ounce, TL deposit interest rate)

BIST 100 Index $=f$ (Lag values of BIST 100 index, USA dollar exchange rate, Gold price in ounce, TL deposit interest rate)

Gold Price in Ounce $=\mathrm{f}$ (Lag values of Gold price in ounce, USA dollar exchange rate, BIST 100 index, TL deposit interest rate)

TL Deposit Rate $=\mathrm{f}$ (Lag values of TL deposit rate, USA dollar exchange rate, BIST 100 index, Gold price in ounce)

The data used in the study are obtained from the website of the Central Bank and private institution. The data cover the periods between January 2015-June 2020, including 284 months. The time period is limited to this interval because of the conversions of the dollar rate and BIST 100 index in the measurement values. Since the conversion in dollar rate and BIST 100 index is thought to cause deterioration in the dataset and lead to negatively affect the learning process, preceding and subsequent periods have not been taken into account.

The following figures illuminate the line graphs of USA dollar Exchange rate, BIST 100 index, gold price in ounce and TL deposit interest rate, respectively, during this period.

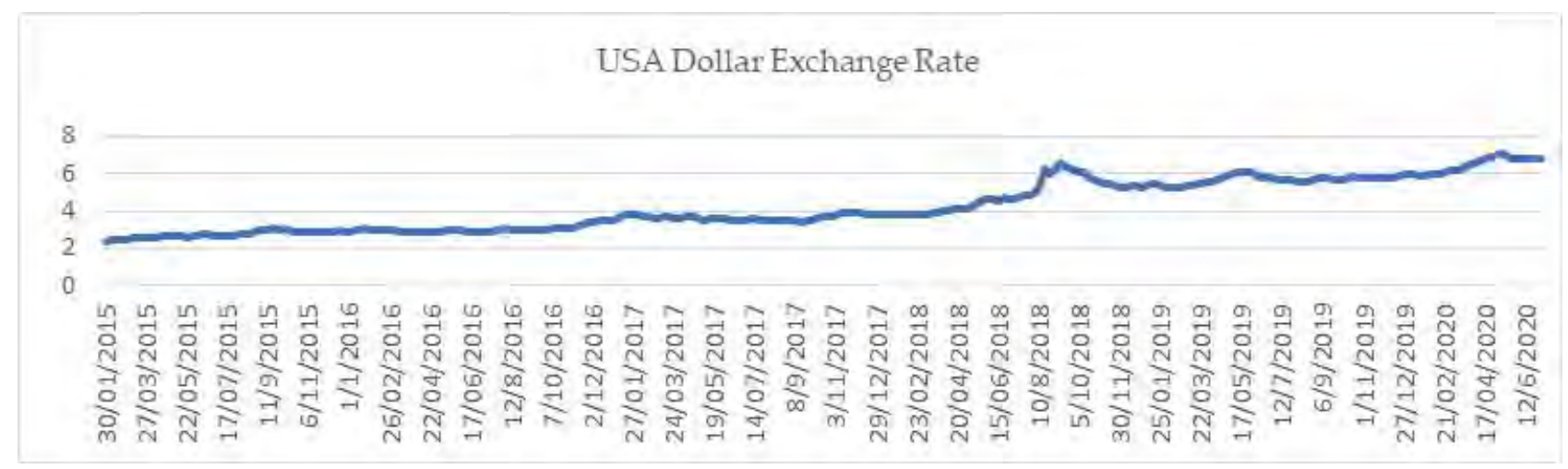

Figure 3. Weekly USA Dollar Exchange Rate Series

It is seen that in Figure 3, USA dollar exchange rate has been in a continuous upward trend. Especially in 2018, there were a big jump, followed by some decline, but never went down to the level prior to the bounce. 


\section{BIST 100 Index}

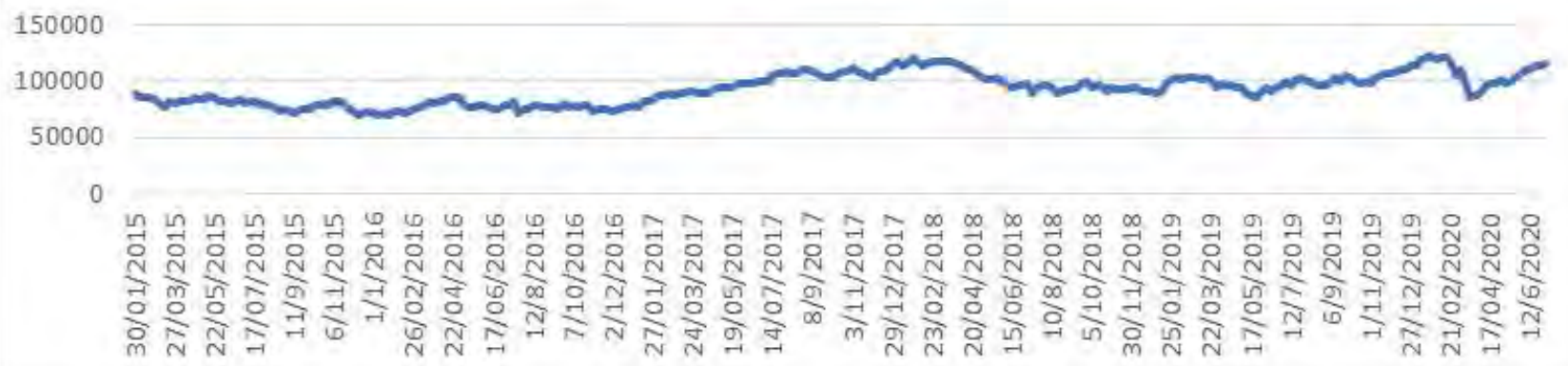

Figure 4. Weekly BIST 100 Index Series

As seen in Figure 4, the BIST 100 Index, on the other hand, has increased since 2017, but then a decline was observed. Finally, it switched to an uptrend again in 2019.

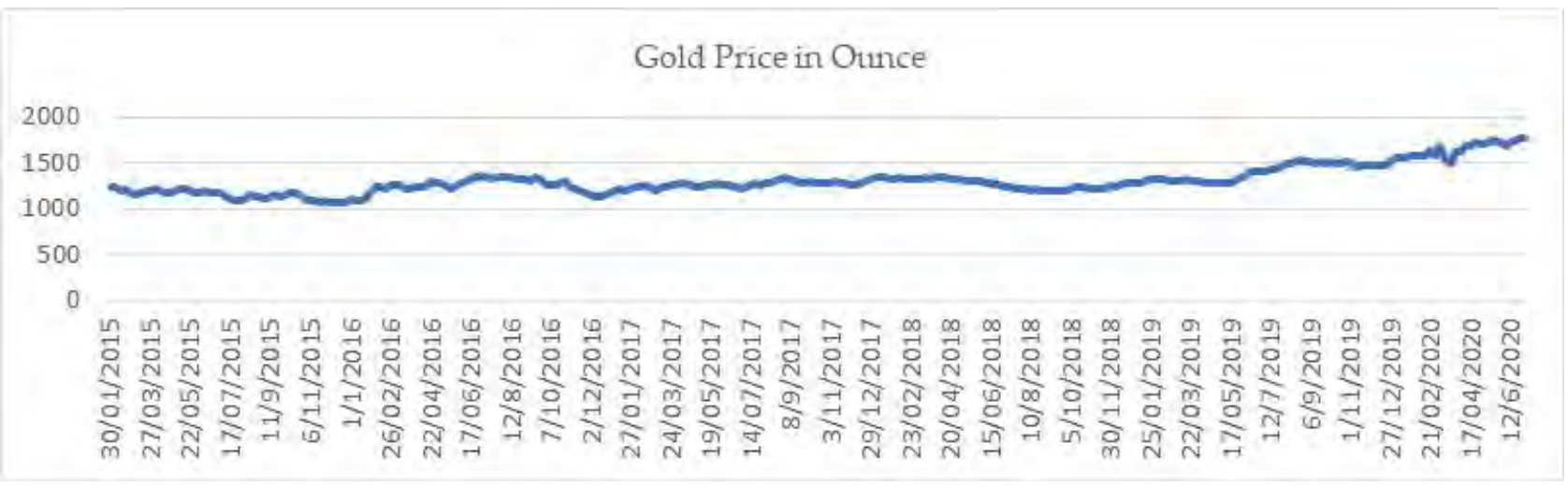

Figure 5. Weekly Gold Price in Ounce Series

The figure 5 illuminates that the gold price in ounce traded in the value range approximately from $1100 \mathrm{TL}$ to 1350 between 2015 and 2018 period then switched to uptrend after 2019 and this uptrend has been continuing so far.

\section{TL Deposit Interest Rate}

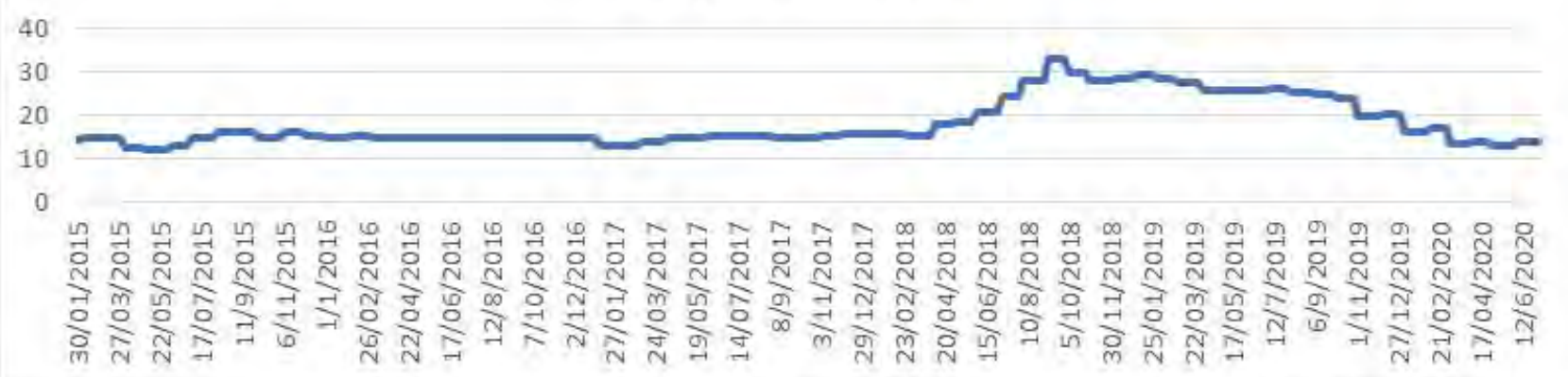

Figure 6. Weekly TL Deposit Interest Rate Series

As seen from Figure 6, TL Deposit interest rate, on the other hand, followed a stable movement until 2018. However, with beginning 2018, it started increasing trend until end of 2018 and then steady decline occurred during 2019 period, although it was seen little change in mid-2019. Again, not much movement was observed in it until the first half of 2020.

\section{ANALYSIS AND FINDINGS}

Prediction models for USA Exchange rate, BIST 100 index, gold price in ounce and TL deposit rate variables were carried out by following the steps of the network development process explained in the method section. 


$$
\text { A. Yildız - D. Yildiz 13/4 (2021) 3103-3118 }
$$

1. Determine Data: The period between January 2015 and June 2020 was taken as the data set. The dataset consists of 284 weekly data in total. For each variable of the data set created and loaded separately to obtain prediction models. Then these data were divided into two groups as the training set and test set. Of this dataset, 238 were used for training and 46 for testing. The same distribution was used for all prediction models.

2. Determine the ANN Architecture: As an ANN architecture, models with different layers such as 3 and 4 were tried. In addition, the number of neurons in each layer was also manipulated during these trials. In these trials of the models, the hyperbolic tangent and logistic functions were used as an activation functions. The error function is selected as mean square error. The stopping criteria for models was determined based on various alternatives such as mean square error or the repetition number.

- ANN Architecture for USA Dollar Exchange Rate

The trial results of the models executed for USA dollar Exchange rate are illustrated in Table 1. According to results, model 11 was detected as the best model based on mean square error. In this model, the hyperbolic tangent function was applied as the activation function of the input and output layers. The $\mathrm{R}^{2}$ value of model was obtained as 0.987

Table 1. Neural Network Models of USA Dollar Exchange Rate

\begin{tabular}{llllll}
\hline $\begin{array}{l}\text { ANN Model } \\
\text { No }\end{array}$ & $\begin{array}{l}\text { Neuron Numbers } \\
\text { in Input Layer }\end{array}$ & $\begin{array}{l}\text { Hidden Layer } \\
\text { Numbers }\end{array}$ & $\begin{array}{l}\text { Neuron } \\
\text { Numbers in } \\
\text { Hidden Layer }\end{array}$ & $\begin{array}{l}\text { Neuron } \\
\text { Numbers in } \\
\text { Output Layer }\end{array}$ & $\begin{array}{l}\text { Mean Square } \\
\text { Error }\end{array}$ \\
\hline 1 & 7 & 1 & 1 & 1 & 0,0385 \\
\hline 2 & 7 & 1 & 18 & 1 & 0,0334 \\
\hline 3 & 5 & 1 & 11 & 1 & 0,0584 \\
\hline 4 & 6 & 1 & 5 & 1 & 0,0405 \\
\hline 6 & 7 & 1 & 7 & 1 & 0,0494 \\
\hline 7 & 6 & 2 & 4,4 & 1 & 0,0521 \\
\hline 8 & 7 & 2 & 6,4 & 1 & 0,0751 \\
\hline 10 & 7 & 1 & 4 & 1 & 0,0433 \\
\hline $\mathbf{1 1}$ & 7 & 1 & 9 & 1 & 0,0365 \\
\hline
\end{tabular}

According to model 11 results, the comparison line graph of the real and prediction of USA dollar exchange rate were demonstrated in Figure 7.

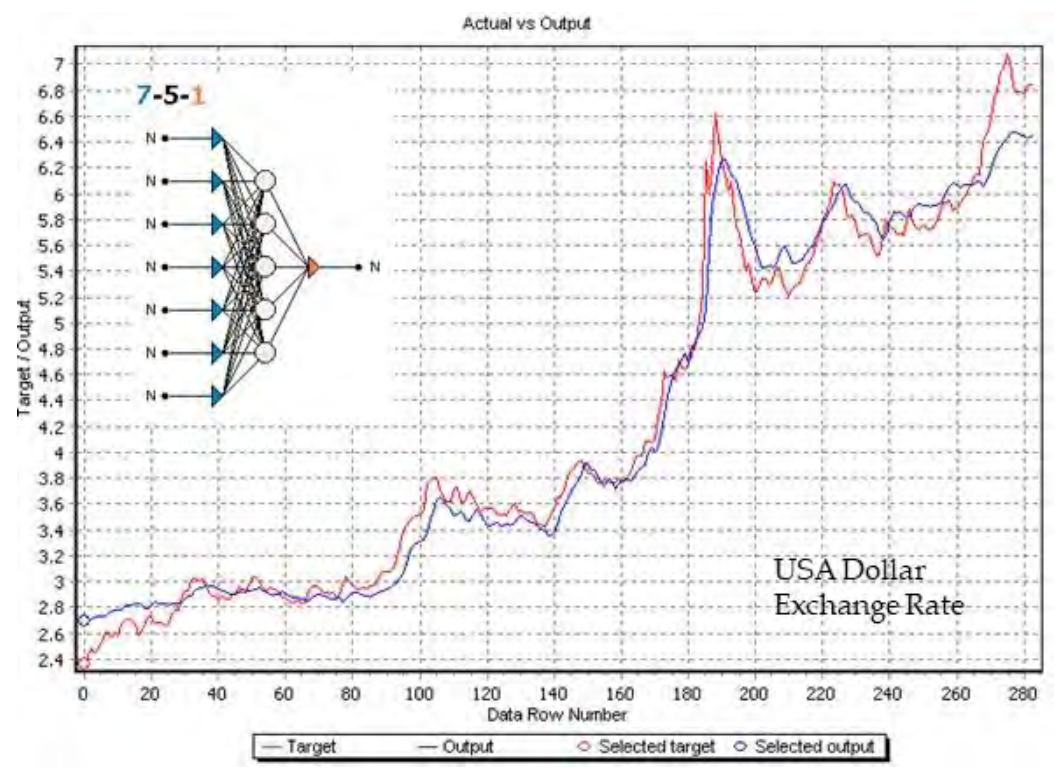

Figure 7. Comparison of Real and Prediction Results for USA Dollar Exchange Rate 


$$
\text { A. Yildız - D. Yildiz 13/4 (2021) 3103-3118 }
$$

From the Figure 7, it can be seen that real and prediction values of USA dollar Exchange rate are very close to each other indicating that the prediction model made a good job.

- ANN Architecture for BIST 100 Index

Table 2 illustrates the results regarding ANN models for BIST 100 index. Based on the results, model 13 was determined as the best model due to giving the minimum mean square error. In this model, logistic function and hyperbolic tangent function were used in the input layer and output layer, respectively. The $\mathrm{R}^{2}$ value of the model was obtained as 0.980 .

Table 2. Neural Network Models for BIST 100 Index

\begin{tabular}{llllll}
\hline $\begin{array}{l}\text { ANN } \\
\text { Model No }\end{array}$ & $\begin{array}{l}\text { Neuron Numbers in } \\
\text { Input Layer }\end{array}$ & $\begin{array}{l}\text { Hidden Layer } \\
\text { Numbers }\end{array}$ & $\begin{array}{l}\text { Neuron } \\
\text { Numbers in } \\
\text { Hidden Layer }\end{array}$ & $\begin{array}{l}\text { Neuron } \\
\text { Numbers in } \\
\text { Output Layer }\end{array}$ & $\begin{array}{l}\text { Mean Square } \\
\text { Error }\end{array}$ \\
\hline 1 & 7 & 1 & 11 & 1 & 7994226 \\
\hline 2 & 4 & 1 & 2 & 1 & 7349484 \\
\hline 3 & 5 & 2 & 3,2 & 1 & 4824205 \\
\hline 4 & 7 & 1 & 7 & 1 & 4528170 \\
\hline 5 & 7 & 1 & 4 & 1 & 6240498 \\
\hline 6 & 8 & 1 & 4 & 1 & 4994825 \\
\hline 7 & 6 & 2 & 4,3 & 1 & 8453347 \\
\hline 8 & 5 & 1 & 3 & 1 & 5343548 \\
\hline 9 & 7 & 2 & 6,4 & 1 & 8423645 \\
\hline 10 & 7 & 1 & 9 & 1 & 9453387 \\
\hline 11 & 7 & 1 & 5 & 1 & 48540281 \\
\hline 12 & 7 & 1 & 8 & 1 & $\mathbf{4 2 6 3 1 1 2}$ \\
\hline $\mathbf{1 3}$ & $\mathbf{7}$ & $\mathbf{1}$ & $\mathbf{6}$ & $\mathbf{1}$ & 7413245 \\
\hline 14 & 7 & 2 & 9,4 & 1 & 6383755 \\
\hline 15 & 6 & 1 & 5 & 1 &
\end{tabular}

The Figure 8 shows the comparative line graph for real value and prediction values. As seen from the Figure the forecasting model results and real values are very close to each other indicating that the forecasting model is successful.

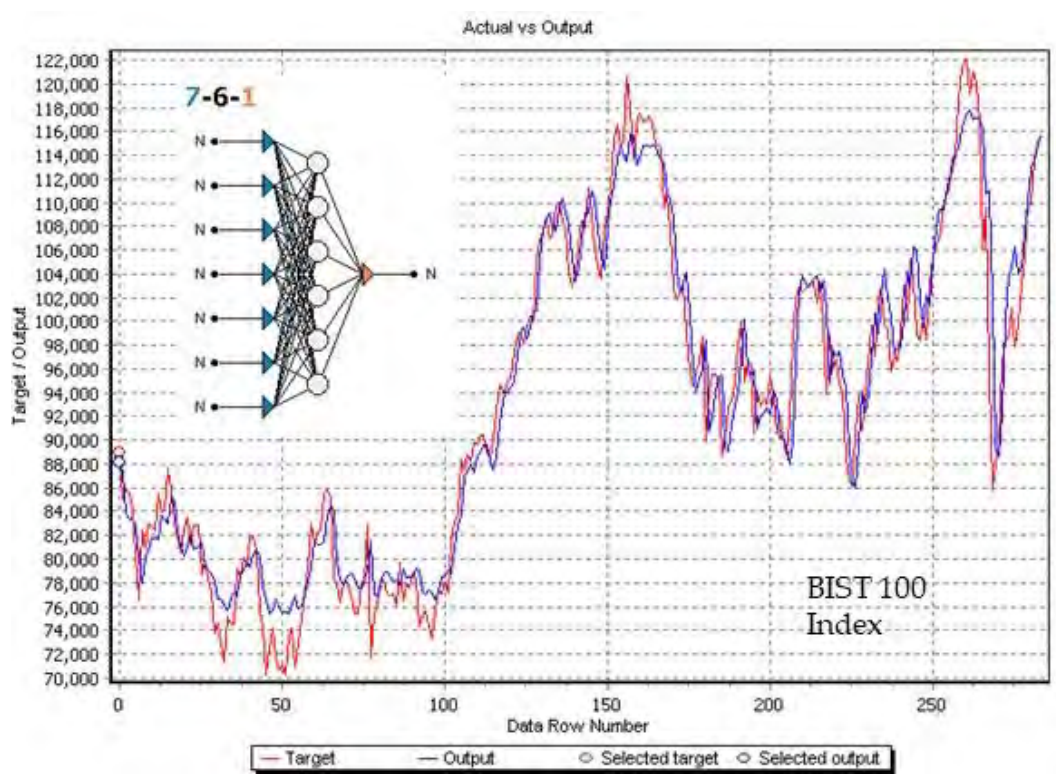

Figure 8: Comparison of Real and Prediction Results for BIST 100 Index 


\section{A. Y1ld1z - D. Y1ldız 13/4 (2021) 3103-3118}

- ANN Architecture for Gold Price in Ounce

Table 3 illustrates the results regarding ANN models for BIST 100 index. Based on the results, model 15 was determined as the best model due to producing the least mean square error. In this model, hyperbolic tangent function was used for both in the input layer and output layer. The $\mathrm{R}^{2}$ value of the model was obtained as 0.930. Results of ANN models developed for gold price in ounce were given in Table 3.

Table 3. ANN Models for Golden Price in Ounce

\begin{tabular}{llllll}
\hline $\begin{array}{l}\text { ANN } \\
\text { Model } \\
\text { No }\end{array}$ & $\begin{array}{l}\text { Neuron } \\
\text { Numbers in } \\
\text { Input Layer }\end{array}$ & $\begin{array}{l}\text { Hidden Layer } \\
\text { Numbers }\end{array}$ & $\begin{array}{l}\text { Neuron } \\
\text { Numbers in } \\
\text { Hidden Layer }\end{array}$ & $\begin{array}{l}\text { Neuron Numbers } \\
\text { in Output Layer }\end{array}$ & $\begin{array}{l}\text { Mean Square } \\
\text { Error }\end{array}$ \\
\hline 1 & 7 & 1 & 1 & 1 & 847,7488 \\
\hline 2 & 7 & 1 & 18 & 1 & 739,5802 \\
\hline 3 & 7 & 1 & 11 & 1 & 652,6691 \\
\hline 4 & 7 & 1 & 7 & 1 & 375,2644 \\
\hline 5 & 7 & 1 & 4 & 1 & 556,6280 \\
\hline 6 & 7 & 1 & 9 & 1 & 423,8417 \\
\hline 7 & 5 & 1 & 3 & 1 & 746,2185 \\
\hline 8 & 6 & 1 & 3 & 1 & 654,2341 \\
\hline 9 & 8 & 1 & 4 & 1 & 443,8541 \\
\hline 10 & 4 & 1 & 2 & 1 & 544,6874 \\
\hline 11 & 7 & 1 & 10 & 1 & 531,8417 \\
\hline 12 & 7 & 2 & 5,3 & 1 & 459,2436 \\
\hline 13 & 6 & 2 & 3,2 & 1 & 454,4236 \\
\hline 14 & 7 & 2 & 4,2 & 1 & $\mathbf{3 5 1 , 4 1 5 4}$ \\
\hline $\mathbf{1 5}$ & $\mathbf{7}$ & $\mathbf{1}$ & $\mathbf{8}$ & $\mathbf{1}$ & 486,2148 \\
\hline 16 & 6 & 1 & 5 & 1 & 592,4512 \\
\hline 17 & 7 & 3 & $5,3,2$ & 1 & \\
\hline
\end{tabular}

Based on the model 15, the prediction results with real values of gold price in ounce illustrated in Figure 9. What stands out in the table is the selected model produced very good prediction results, exception with some last terms.

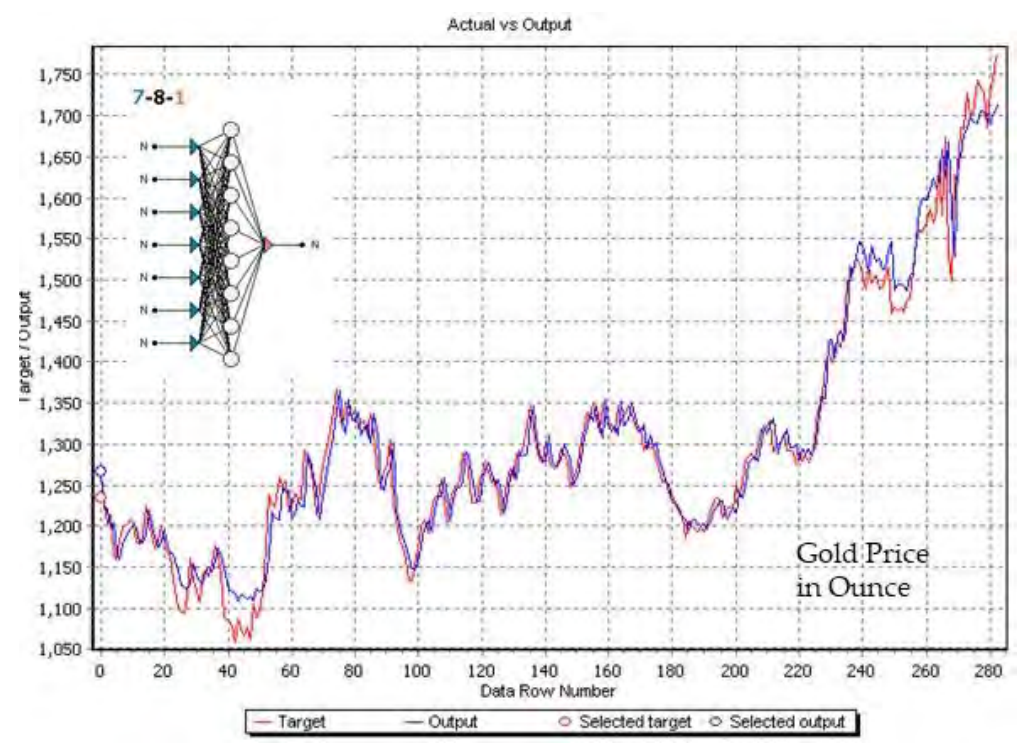

Figure 9. Comparison of Real and Prediction Results for Gold Price in Ounce

- ANN Architecture for TL Deposit interest rate

The alternative ANN models as to TL deposit interest rate is given in Table 4 below. According to results obtained Model 8 was determined the most appropriate model due to having the minimum mean square error. 


$$
\text { A. Yildiz - D. Yildiz 13/4 (2021) 3103-3118 }
$$

In this model, the hyperbolic tangent in the input layer and the logistic activation function in the output layer were applied, respectively. The $\mathrm{R}^{2}$ value of this model was acquired as 0,977 indicating that the explanatory power of the model is quite high.

Table 4. ANN Models for TL Deposit Interest Rate

\begin{tabular}{llllll}
\hline ANN & Neuron & Hidden & Neuron & Neuron & Mean Square \\
Model & Numbers in & Layer & Numbers in & Numbers in \\
No & Input Layer & Numbers & Hidden Layer & Output Layer & \\
\hline 1 & 7 & 1 & 1 & 1 & 1,5427 \\
\hline 2 & 7 & 1 & 18 & 1 & 7,2131 \\
\hline 3 & 7 & 1 & 11 & 1 & 1,2981 \\
\hline 4 & 6 & 1 & 8 & 1 & 4,1297 \\
\hline 5 & 8 & 1 & 4 & 1 & 5,6432 \\
\hline 6 & 5 & 1 & 2 & 1 & 1,9546 \\
\hline 7 & 7 & 1 & 7 & 1 & 0,6103 \\
\hline $\mathbf{8}$ & $\mathbf{7}$ & $\mathbf{1}$ & $\mathbf{4}$ & $\mathbf{1}$ & $\mathbf{0 , 4 5 4 6}$ \\
\hline 10 & 7 & 1 & 5 & 1 & 0,5254 \\
\hline 11 & 7 & 1 & 2 & 1 & 1,1445 \\
\hline 12 & 7 & 1 & 3 & 1 & 0,9537 \\
\hline 13 & 7 & 2 & 6,4 & 1 & 5,3265 \\
\hline 14 & 6 & 2 & 10,5 & 1 & 8,4572 \\
\hline
\end{tabular}

The forecasting value of TL deposit interest rate applying the ANN 8 model and the value of it results were compared and demonstrated in Figure 10. It is apparent from this table that very few deviations occurred between the real and prediction values.

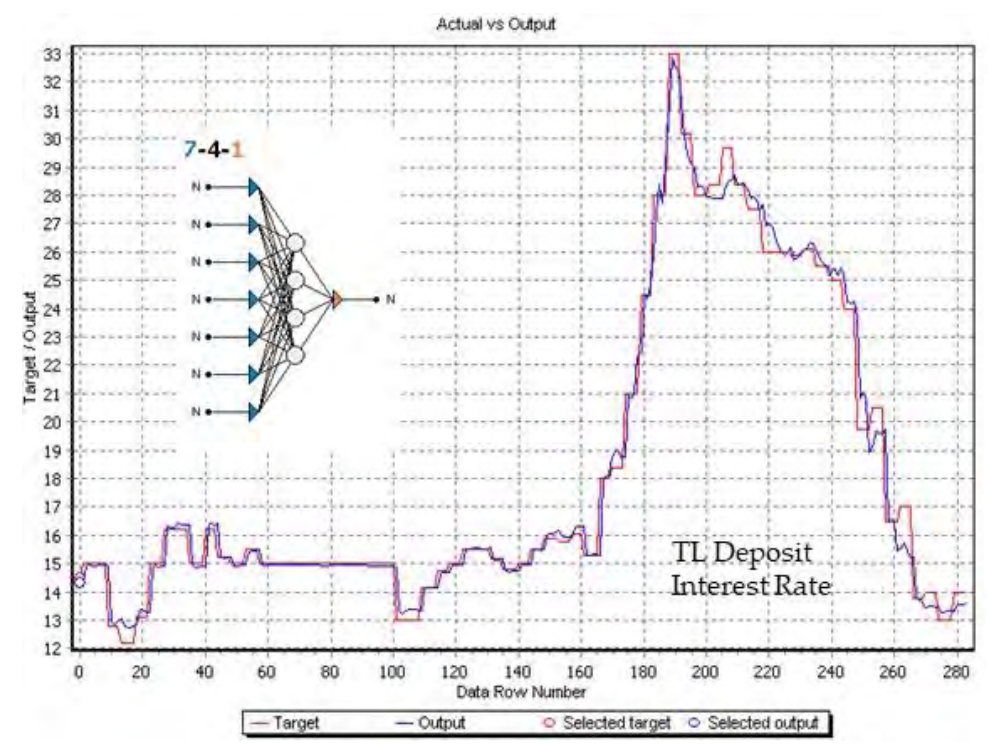

Figure 10. Comparison of Real and Prediction Results for TL Deposit Interest Rate

3.Train the Network: The fast backpropagation algorithm was conducted as the learning algorithm. The data were processed in the network in a sequential way. As the stopping criteria, different attempts carried out such as minimum mean square error and certain number for repetition setting up between 2000 and 50000. Based on this set up configuration, the results of ANN models are explained in the following ways.

Regarding USA dollar Exchange rate, Model 11 found as the most appropriate as shown in Table. The results of the table indicate that much of the change in it stems from lag 1,2, and 3 values as effective factors and following by gold price in ounce, BIST 100 index, lag 4 and finally TL deposit interest rate, respectively. All these factors can impact on the value of USA dollar exchange rate. 


\section{A. Yildız - D. Yildiz 13/4 (2021) 3103-3118}

With respect to BIST 100 index, model 13 as shown in Table 2 was found as the most appropriate model and the model indicates that lag 2 value significantly impact on BIST 100 index and the other factors based on their influence were found as TL deposit interest rate, golden price in ounce, lag 1 and lag 3 values of it, USA dollar exchange rate and finally lag 4 value, respectively.

Concerning gold price in ounce, model 15 was determined as the most appropriate model. The results of this model revealed that lag 3 value was significant factor to the change of it and following factors were lag 4 , lag 1, BIST 100 index, TL deposit interest rate, USA exchange rate and finally lag 2, respectively.

With regard to TL deposit interest rate, Model 8 illustrated in Table 4 was selected as the most suitable model indicating that lag 1 value was the confounding factor on it and following factors, respectively, as lag 4, USA dollar exchange rate, lag 2, gold price in ounce, lag 3 and finally BIST 100 index.

4. Deployment the model: The models providing prediction with minimum mean square error were chosen as the best appropriate models for training. These models were namely model 11 for US dollar rate, model 13 for BIST 100 index, model 15 for gold price in ounce and finally model 8 for TL deposit interest rate. Then these models were carried out to predict for last three weeks which are the test period. The prediction results with error rates are given in Table 4.

Table 5. Error Rates for Three Weeks Period

\begin{tabular}{|c|c|c|c|c|c|c|c|c|c|}
\hline & \multicolumn{3}{|c|}{$10-07-2020$} & \multicolumn{3}{|c|}{$17-07-2020$} & \multicolumn{3}{|c|}{$24-07-2020$} \\
\hline & $\begin{array}{l}\text { Real } \\
\text { Value }\end{array}$ & $\begin{array}{l}\text { Prediction } \\
\text { Value }\end{array}$ & $\begin{array}{l}\text { Error } \\
\text { Rate }\end{array}$ & $\begin{array}{l}\text { Real } \\
\text { Value }\end{array}$ & $\begin{array}{l}\text { Prediction } \\
\text { Value }\end{array}$ & $\begin{array}{l}\text { Error } \\
\text { Rate }\end{array}$ & $\begin{array}{l}\text { Real } \\
\text { Value }\end{array}$ & $\begin{array}{l}\text { Prediction } \\
\text { Value }\end{array}$ & $\begin{array}{l}\text { Error } \\
\text { Rate }\end{array}$ \\
\hline $\begin{array}{l}\text { USA dollar } \\
\text { rate }\end{array}$ & 6,85 & 6,75 & 0,014 & 6,85 & 6,88 & $-0,004$ & 6,84 & 6,82 & 0,002 \\
\hline $\begin{array}{l}\text { BIST } 100 \\
\text { Index }\end{array}$ & 115,793 & 115,702 & 0,000 & 118,786 & 117985 & 0,006 & 119201 & 121012 & $-0,015$ \\
\hline $\begin{array}{l}\text { Gold price in } \\
\text { ounce }\end{array}$ & 1798 & 1756 & 0,023 & 1810 & 1796 & 0,007 & 1901 & 1894 & 0,026 \\
\hline $\begin{array}{l}\text { TL Deposit } \\
\text { interest rate }\end{array}$ & 14 & 13,90 & 0,007 & 14 & 13,97 & 0,002 & 14 & 14,05 & $-0,003$ \\
\hline
\end{tabular}

As seen from Table 5, the prediction values obtained by using the most appropriate models as previously implied are very close to the real values. Indeed, the high performance of the BIST 100 index prediction, which is the most difficult to predict in an uncertain environment, is remarkable and almost no prediction error is observed for 10.07.2020 period.

The obvious finding from these analyses is indicate that the most influencing factor in future values of investment alternatives is their lag values, which state that significant contribution of these those in prediction. This result may also be interpreted as in a way that all other influential variables are somehow reflected in the historical values of investment alternatives. According to the results obtained, it can be inferred that time series data are much more appropriate to predict financial and economic data than the influencing factors.

\section{CONCLUSION AND DISCUSSION}

Studies in the literature regarding the prediction applying ANN models have been carried out on single variable estimation and they are generally based on the comparison of used methods. However, the correct determination of the model inputs is crucial point besides the correction the model. Therefore, the aim of this study is to develop multidimensional prediction models for alternative investments simultaneously which are affecting each other, instead of estimating only one single investment. Thus, it may be possible to make contribution for investment decision makers. For this aim, USA dollar exchange rate, BIST 100 index, gold price in ounce and TL deposit interest rate were taken as investment alternatives. To calculate the prediction of each investment values based on their lag values with the values of other investment alternatives. The time period covered the weekly data between January 2015 and June 2020.

Then this dataset is used to develop ANN models by following the steps described in networking process. When the actual and predict values of each investment alternative values are compared, it is seen that these 


$$
\text { A. Yildiz - D. Yildiz 13/4 (2021) 3103-3118 }
$$

two values are very close to each other. $R^{2}$ values indicating explanatory power of the models are also found quite high.

As the models are examined on the basis of influencing factor, the lag values of each investment emerge as the most effective factors. This result explains why the ANN method produces such successful prediction results. As stated before, the ANN algorithm is conducted to determine the appropriate model based on the past data.

As a result, it can be expected that the ANN models, which use the time series data in the prediction of investments, can yield more successful results. However, in this approach, break points such as 2008 global financial crises or the COVID-19 pandemic case and autocorrelation problem which may be arise in the analysis must be considered to increase the prediction power of the models.

Analyzes were carried out using 284 weekly data covering the period from January 2015 to June 2020. This time period may be considered limited. The reason of this limitation is that the different data scale has been used for USA dollar Exchange rate and BIST 100 index out of this period. In order to prevent any deviant result because of inconsistency dataset has led to this limitation. Further expansion of the dataset may improve to the learning process of the algorithm, which increases the prediction performance.

In addition, the determination of the parameters by using optimization methods in the constructing of the network architecture allows the process of the algorithm to obtain better prediction results in a shorter time.

\section{REFERENCES}

Akel, V., \& Karacameydan, F. (2012). Yatırım Fonları Net Varlık Değerlerinin Yapay Sinir Ağları Yöntemiyle Tahmin Edilmesi. Anadolu Üniversitesi Sosyal Bilimler Dergisi, 12(2), 87-106.

Akyurt, İ. Z. (2015). Talep Tahmininin Yapay Sinir Ağlarıyla Modellenmesi: Yerli Otomobil Örneği. Ekonometri ve İstatistik(23), 147-157.

Ataseven, B. (2013). Yapay Sinir Ağları İle Öngörü Modellemesi. Öneri, 10(39), 101-115.

Aygören, H., Sarıtaş, H., \& Moralı, T. (2012). İMKB 100 Endeksinin Yapay Sinir Ağları ve Newton Nümerik Arama Modelleri ile Tahmini. Uluslararası Alanya İşletme Fakültesi Dergisi, 4(1), 73-88.

Barkhatov, N. A., Revunov, S. E., Smirnova, Z. V., Cherney, O. T., \& Katkova, O. V. (2020). Using Neural Network for forecasting in the Financial Sector. International Journal of Advanced Trends in Computer Science and Engineering, 9(3), 3121-3124.

Benli, Y. K., \& Yıldız, A. (2014). Altın Fiyatının Zaman Serisi Yöntemleri Ve Yapay Sinir Ağları İle Öngörüsü. Dumlupinar Üniversitesi Sosyal Bilimler Dergisi(42).

Çalışkan, M. M., \& Deniz, D. (2015). Yapay Sinir Ağlarıyla Hisse Senedi Fiyatları ve Yönlerinin Tahmini. Eskişehir Osmangazi Üniversitesi İ̈BF Dergisi, 10(3), 177-194.

Çınaroğlu, E., \& Avcı, T. (2020). THY Hisse Senedi Değerinin Yapay Sinir Ağları İle Kestirimi. Atatürk Üniversitesi, İktisadi ve İdari Bilimler Dergisi, 34(1).

Çuhadar, M. (2013). Türkiye'ye Yönelik Dış Turizm Talebinin MLP, RBF Ve TDNN Yapay Sinir Ağı Mimarileri İle Modellenmesi Ve Tahmini: Karşılaştırmalı Bir Analiz. Journal of Yasar University, 8(31), 5274-5295.

Es, H. A., Kalender, F. Y., \& Hamzaçebi, C. (2014). Yapay Sinir Ağları İle Türkiye Net Enerji Talep Tahmini. Gazi Üniv. Müh. Mim. Fak. Der., 29(3), 495-504.

Galeshchuk, S. (2016). Neural networks performance in exchange rate prediction. Neurocomputing,, 172, 446452.

Gradojevic, N., \& Yang, J. (2000). The Application of Artificial Neural Networks to Exchange Rate Forecasting: The Role of Market Microstructure Variables. Bank Of Canada Working Paper. 


$$
\text { A. Y1ld1z - D. Yildiz 13/4 (2021) 3103-3118 }
$$

Haykin, S. (1999). Neural Networks A Comprehensive Foundation. Prentice - Hall.

Hosaka, T. (2018). Bankruptcy prediction using imaged financial ratios and convolutional neural networks. Expert Systems with Applications, 09(39).

İnce, H., \& Çakır, F. S. (2017). Model Melezleme İle Finansal Zaman Serisi Analizi. Journal of Economics, Finance and Accounting, 4(3).

Kaastra, I., \& Boyd, M. (1996). Designing a Neural Network for Forecasting Financial and Economic Time Series. Neurocomputing, 10, 215-236.

Kantar, L. (2019). BİST100 Endeksinin Yapay Sinir Ağları Ve ARMA Modeli İle Tahmini. 23. Uluslararası Finans Sетровучти.

Karahan, M. (2015). Turizm Talebinin Yapay Sinir Ağaları Yöntemiyle Tahmin Edilmesi. Süleyman Demirel Üniversitesi İktisadi ve İdari Bilimler Fakültesi Dergisi, 20(2), 195-209.

Kaynar, O., Taştan, S., \& Demirkoparan, F. (2011). Yapay Sinir Ağları İle Doğalgaz Tüketim Tahmini. Atatürk Ü. İ̈BF Dergisi, 463-474.

Kocatepe, C. İ., \& Oktay. Y. (2016). Ekonomik Endeksler Kullanılarak Türkiye'deki Altın Fiyatındaki Değişim Yönünün Yapay Sinir Ağları İle Tahmini. Düzce Üniversitesi Bilim ve Teknoloji Dergisi, 4, 926-934.

Nwokike , C. C., Chukwuma , B., Maxwell, O., Uche-Ikonne, O. O., Offorha, B. C., \& Ukomah, H. I. (2020). Forecasting Monthly Prices of Gold Using Artificial Neural Network. Journal of Statistical and Econometric Methods, 9(3), 19-28.

Özkan, F. (2011). Döviz Kuru Tahmininde Yapay Sinir Ağlarıyla Alternatif Yaklaşım. Eskişehir Osmangazi Üniversitesi İ̈BF Dergisi, 6(2), 185-200.

Persio, L., \& Honchar, O. (2016). Artificial Neural Networks architectures for stock price prediction: comparisons and applications. Internatıonal Journal Of Circuits, Systems And Signal Processing, 10.

Polat, Ö., \& Temurlenk, S. (2011). Yapay Sinir Ağları Metodolojisi ile Makroekonomik Zaman Serilerinde Ongoru Modellemesi. Dicle Üniversitesi İktisadi ve İdari Bilimler Fakültesi Dergisi, 1(2), 98-106.

Selvamuthu, D., Kumar, V., \& Mishra, A. (2019). Indian stock market prediction using artificial neural networks on tick data. Financial Innovation, 5(1).

Şahin, E. E. (2018). Kripto Para Bitcoin: ARIMA ve Yapay Sinir Ağları İle Fiyat Tahmini. Fiscaoeconomia, 2(2), 74-92.

Şeker, M., Yıldırım, E. S., \& Berkay, A. (2004). Yapay Sinir Ağlarının Ekonomik Tahminlerde Kullanılması. Pamukkale Üniversitesi Mühendislik Fakültesi, 10(Özel Sayı), 79-83.

Warner, B., \& Misra, M. (1996). Understanding Neural Networks As Statistical Tool. The American Statistician, 50(4).

Yavuz, U., Özen, Ü., Taş, K., \& Çağlar, B. (2020). Yapay Sinir Ağları ile Blockchain Verilerine Dayalı Bitcoin Fiyat Tahmini. Bilişim Sistemleri ve Yönetim Araştırmaları Dergisi, 2(1), 1-9.

Yıldız, A., \& Yıldız, D. (2014). BIST 100 Endeksi'nin ARIMA ve Yapay Sinir Ağlarına Dayalı Karma Yöntem İle Tahmini. Finans, Politik ve Ekonomik Yorumlar, 51(588).

Yıldız, D. (2009). Zaman Serileri Analizi ve Yapay Sinir Ağları ile Tahmin: Yabancı Portföy Yatırımları Üzerine Uygulama. Ankara Üniversitesi Sosyal Bilimler Enstitüsü, Yayımlanmamış Doktora Tezi. 
A. Yıldiz - D. Yildiz 13/4 (2021) 3103-3118

Yıldız, D. (2021). Koronavirüs Pandemisi Döneminde Tüketici Kredi Faiz Oranının Yapay Sinir Ağları ile Öngörülmesi. International Symposium on Business, Economics, and education ISBE 2021 (pp. 192-204). Ankara: Gazi Kitabevi.

Yu, P., \& Yan, X. (2019). Stock price prediction based on deep neural networks. Neural Computing and Applications.

Yüksel, R., \& Akkoç, S. (2016). Altın Fiyatlarının Yapay Sinir Ağları İle Tahmini Ve Bir Uygulama. Doğuş Üniversitesi Dergisi, 17(1), 39-50.

Zhang, G. P. (2003). Time series forecasting using a hybrid ARIMA and neural network model. Neurocomputing, 50, 159-175.

Zhang, G., Hu, M. Y., Patuwo, B. E., \& Indro, D. C. (1999). Artificial neural networks in bankruptcy prediction: General framework and cross-validation analysis. European Journal of Operational Research, 116(1), 1632. 